\title{
COMPARATIVE ANALYSIS OF STEEL TELECOMMUNICATION TOWER SUBJECTED TO SEISMIC \& WIND LOADING
}

\author{
Keshav Kr. Sharma ${ }^{1}$, S.K.Duggal ${ }^{2}$, Deepak Kumar Singh $^{1}$ and A.K.Sachan ${ }^{2}$ \\ ${ }^{1}$ Research Scholar, Department of Civil Engineering, MNNIT Allahabad \\ ${ }^{2}$ Professor, Department of Civil Engineering, MNNIT Allahabad
}

\begin{abstract}
Over the past 30 years, the growing demand for wireless and broadcast communication has spurred a dramatic increase in communication tower construction and maintenance. Failure of such structures is a major concern. In this paper a comparative analysis is being carried out for different heights of towers using different bracing patterns for Wind zones I to VI and Earthquake zones II to V of India. Gust factor method is used for wind load analysis, modal analysis and response spectrum analysis are used for earthquake loading. The results of displacement at the top of the towers and stresses in the bottom leg of the towers are compared.
\end{abstract}

\section{KEYWORDS}

Steel communication towers; Bracings; Wind analysis; Gust factor method; Modal analysis; Response spectrum analysis

\section{INTRODUCTION}

Fastest growing telecommunication market has increased the demand of steel towers. The major loads considered for design of these towers are self-weight, wind load, seismic load, antenna load, platform load, steel ladder load etc. Failure of towers is generally due to high intensity winds. Several studies have been carried out by considering wind and earthquake loads.

Jithesh Rajasekharan et al. (2014) designed the lattice tower for three heights of 30m, 40m and $50 \mathrm{~m}$ with different types of bracings to study the effect of wind load on 4- legged lattice tower for wind zone V and VI using gust factor method. They also studied the seismic effect on the tower structures by carrying out the modal analysis and response spectrum analysis for zone II to zone $\mathrm{V}$ and concluded that the member stresses in bottom leg of $\mathrm{XX}$ braced tower are higher as compared to other tower models. The frequency of the tower with Y bracing displayed the least natural frequency since its stiffness was found to be higher due to more weight of the structure as compared to other models. It was observed that from $30 \mathrm{~m}$ to $40 \mathrm{~m}$ tower height, the increase in displacement is nearly linear but as the height increases from $40 \mathrm{~m}$ to $50 \mathrm{~m}$ there is a steep increase in the displacement in all the zones.

Siddesha. H (2010) presented the analysis of microwave antenna tower with Static and Gust factor method and compared the towers with angle and square hollow sections. The displacement at the top of the tower was considered as the main parameter. The towers with different configuration have also been analyzed by removing one member present in the regular tower in

DOI : 10.5121/civej.2015.2303 
lower panels. Square sections were found to be most effective for legs as compared to the angle sections. Square hollow sections used in bracing along with the leg members did not show any appreciable reduction of displacement. X-type and M-type bracings in square hollow sections for legs and bracings in the lower first panel of towers showed maximum reduction in displacement as compared to the regular towers with angle sections.

A. Jesumi.et al. (2013) modeled five steel lattice towers with different bracing configurations such as the $\mathrm{X}-\mathrm{B}$, single diagonal, $\mathrm{X}-\mathrm{X}, \mathrm{K}$ and $\mathrm{Y}$ bracings for a given range of height. The heights of the towers are $40 \mathrm{~m}$ and $50 \mathrm{~m}$ with a base width of $2 \mathrm{~m}$ and $5 \mathrm{~m}$ respectively. The tower of height $40 \mathrm{~m}$ has 13 panels and the tower of height $50 \mathrm{~m}$ has 16 panels. $70-72 \%$ of the height is provided for the tapered part and $28-30 \%$ of the height is provided for the straight part of the tower. The towers have been analyzed for wind loads with STAAD Pro. V8i, to compare the maximum joint displacement of each tower. Optimized design has been carried out to estimate and to compare the weight of each tower. From the results obtained, Y bracing has been found to be the most economical bracing system up to a height of $50 \mathrm{~m}$.

Silva.et.al. (2005) presented paper on an alternative structural analysis modeling strategy for the steel tower design considering all the actual structural forces and moments combining threedimensional beam and truss finite elements. Comparisons of the two above-mentioned design methods with a third method based on the use of spatial beam finite elements to model the main structure and the bracing system on two actually built steel telecommunication towers (40 and 75 $\mathrm{m}$ high steel towers) have been described. Generally in all the cases studied the maximum stress values for the structural tower modeling based on the three investigated methodologies were significantly modified. The lateral displacement values were not significantly changed when the usual truss model, the beam model or the combined beam and truss model were considered.

The objective of the present work is to study the effect of wind and earthquake load for different heights of the tower structures with different possible arrangements of bracing systems for all of the wind and earthquake zones of India. Gust factor method for wind loading, modal analysis and response spectrum analysis for earthquake loading have been considered. This paper helps in understanding the effect of both wind and seismic forces on the tower structures by considering different height of towers with different bracing systems.

\subsection{MODELING OF TOWER}

The Steel Communication tower is designed for heights of $25 \mathrm{~m}, 35 \mathrm{~m}$ and $45 \mathrm{~m}$. The towers are provided with 5-different types of bracings: $\mathrm{K}$ type, XBX-type, V-type, $\mathrm{W}$-type, XX-type for lower portion and X-Bracing for upper portion of tower. STAAD Pro. V8i has been used for modeling, analysis and design of towers. Details of towers used for modeling are given in Table-I for various heights. Fig. 1 shows $45 \mathrm{~m}$ high towers with different types of bracings considered in the study. Table II to Table IV show the member properties assigned to towers for different heights. 
Civil Engineering and Urban Planning: An International Journal(CiVEJ) Vol.2,No.3, September 2015

Table I: Details of Towers

\begin{tabular}{|c|c|c|c|}
\hline Height of tower & $45 \mathrm{~m}$ & $35 \mathrm{~m}$ & $25 \mathrm{~m}$ \\
\hline Height of slant portion & $38 \mathrm{~m}$ & $31 \mathrm{~m}$ & $22 \mathrm{~m}$ \\
\hline Height of straight portion at top of tower & $7 \mathrm{~m}$ & $4 \mathrm{~m}$ & $3 \mathrm{~m}$ \\
\hline Base width & $6.5 \mathrm{~m}$ & $6.5 \mathrm{~m}$ & $6.5 \mathrm{~m}$ \\
\hline Top width & $1.5 \mathrm{~m}$ & $1.5 \mathrm{~m}$ & $1.5 \mathrm{~m}$ \\
\hline
\end{tabular}

Table II: Member Details of 45m Tower

\begin{tabular}{|c|c|c|c|c|c|}
\hline \multirow{2}{*}{ Height(45m) } & $0-8$ & 8-20 & $20-30$ & $30-38$ & $38-45$ \\
\hline & \multicolumn{5}{|c|}{ ISA section used } \\
\hline Main leg & $200 \times 200 \times 18$ & $150 \times 150 \times 18$ & $110 \times 110 \times 15$ & $100 \times 100 \times 12$ & $90 \times 90 \times 6$ \\
\hline $\begin{array}{c}\text { Horizontal } \\
\text { members }\end{array}$ & $80 \times 80 \times 10$ & $80 \times 80 \times 10$ & $60 \times 60 \times 10$ & $70 \times 70 \times 6$ & $60 \times 60 \times 10$ \\
\hline Primary bracing & $110 \times 110 \times 15$ & $100 \times 100 \times 12$ & $80 \times 80 \times 10$ & $60 \times 60 \times 10$ & $45 \times 45 \times 6$ \\
\hline $\begin{array}{c}\text { Secondary } \\
\text { bracing }\end{array}$ & $70 \times 70 \times 6$ & $70 \times 70 \times 6$ & $45 \times 45 \times 6$ & Nil & Nil \\
\hline $\begin{array}{c}\text { Horizontal } \\
\text { bracing }\end{array}$ & $70 \times 70 \times 6$ & $70 \times 70 \times 6$ & $60 \times 60 \times 10$ & $70 \times 70 \times 6$ & $60 \times 60 \times 10$ \\
\hline
\end{tabular}

Table III: Member Details of 35m Tower

\begin{tabular}{|c|c|c|c|}
\hline \multirow{2}{*}{ Height $(35$ m) } & 0-16 m & 16-26 m & 26-35 m \\
\cline { 2 - 4 } & \multicolumn{2}{|c|}{ ISA section used } & $80 \times 80 \times 12$ \\
\hline Main leg & $150 \times 150 \times 18$ & $110 \times 110 \times 15$ & $70 \times 70 \times 10$ \\
\hline Horizontal members & $70 \times 70 \times 10$ & $70 \times 70 \times 10$ & $65 \times 65 \times 10$ \\
\hline Primary bracing & $100 \times 100 \times 12$ & $80 \times 80 \times 10$ & Nil \\
\hline Secondary bracing & $70 \times 70 \times 10$ & $60 \times 60 \times 10$ & $70 \times 70 \times 10$ \\
\hline Horizontal bracing & $70 \times 70 \times 10$ & $70 \times 70 \times 10$ & \\
\hline
\end{tabular}


Civil Engineering and Urban Planning: An International Journal(CiVEJ) Vol.2,No.3, September 2015

Table IV: Member Details of 25m Tower

\begin{tabular}{|c|c|c|c|}
\hline \multirow{2}{*}{ Height(25m) } & 0-12 & 12-18 & 18-25 \\
\cline { 2 - 4 } & \multicolumn{2}{|c|}{ ISA section used } & $80 \times 80 \times 10$ \\
\hline Main leg & $110 \times 110 \times 15$ & $90 \times 90 \times 12$ & $55 \times 55 \times 8$ \\
\hline Horizontal members & $65 \times 65 \times 10$ & $65 \times 65 \times 10$ & $60 \times 60 \times 8$ \\
\hline Primary bracing & $100 \times 100 \times 10$ & $70 \times 70 \times 10$ & Nil \\
\hline Secondary bracing & $70 \times 70 \times 10$ & $55 \times 55 \times 10$ & $60 \times 60 \times 8$ \\
\hline
\end{tabular}

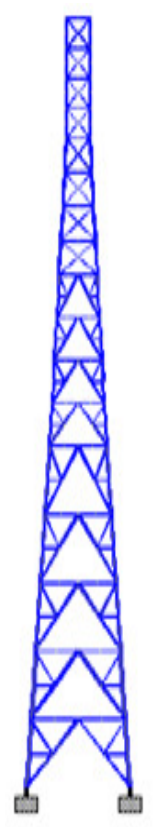

K-Bracing

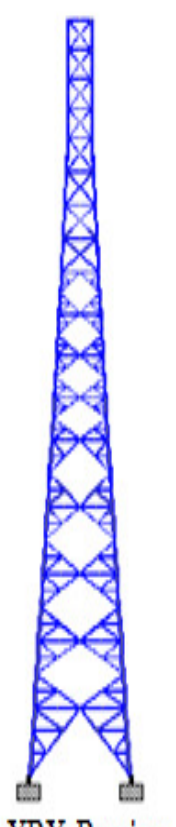

XBX-Bracing

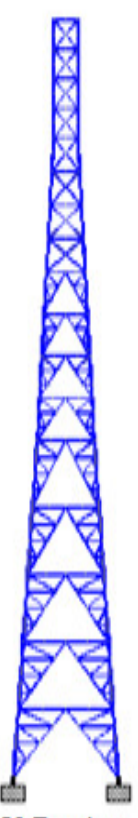

V-Bracing

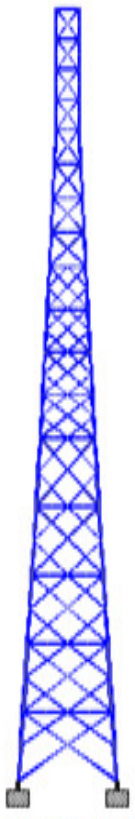

W-Bracing

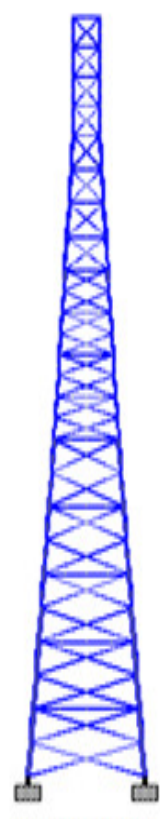

XX-Bracing

Fig. 1: 45m Towers with Different Bracings Considered 


\section{LOADS ON TOWER}

A platform load of $0.82 \mathrm{kN} / \mathrm{m} 2$ is applied at $22 \mathrm{~m}, 32 \mathrm{~m}$, and $42 \mathrm{~m}$ for $25 \mathrm{~m}, 35 \mathrm{~m}$, and $45 \mathrm{~m}$ respectively. Weight of the ladder and cage assembly is assumed to be $10 \%$ of total weight.

Table V: Antenna Loading for the Towers

\begin{tabular}{|c|c|c|c|c|c|c|c|}
\hline $\begin{array}{l}\text { S. } \\
\text { No }\end{array}$ & Item & Quantity & $\begin{array}{l}\text { Diameter } \\
\text { (m) }\end{array}$ & $\begin{array}{c}\text { Weight } \\
\text { of } \\
\text { antenn } \\
\text { a } \\
(\mathrm{kg}) \\
\end{array}$ & $\begin{array}{c}\text { Location } \\
\text { from base } \\
(25 \mathrm{~m}- \\
\text { tower })\end{array}$ & $\begin{array}{c}\text { Location } \\
\text { from base } \\
\text { (35 m- } \\
\text { tower) }\end{array}$ & $\begin{array}{c}\text { Location } \\
\text { from } \\
\text { base } \\
\text { (45 m- } \\
\text { tower) }\end{array}$ \\
\hline 1. & CDMA & 6 & $0.26 \times 2.5$ & 20 & $23 \mathrm{~m}$ & $33 m$ & $43 m$ \\
\hline 2. & $\begin{array}{c}\text { Microwav } \\
\mathrm{e}\end{array}$ & 1 & 1.2 & 77 & $20 \mathrm{~m}$ & $30 \mathrm{~m}$ & $40 \mathrm{~m}$ \\
\hline 3. & $\begin{array}{c}\text { Microwav } \\
\mathrm{e}\end{array}$ & 1 & 0.6 & 45 & $20 \mathrm{~m}$ & $30 \mathrm{~m}$ & $40 \mathrm{~m}$ \\
\hline 4. & $\begin{array}{c}\text { Microwav } \\
\text { e }\end{array}$ & 2 & 0.3 & 25 & $20 \mathrm{~m}$ & $30 \mathrm{~m}$ & $40 \mathrm{~m}$ \\
\hline
\end{tabular}

\subsection{WIND LOAD}

IS 875 (part 3): 1987 and IS 802 (Part 1:Sec1)-1995 are referred to estimate wind loads on the towers. Design wind speed $\left(V_{z}\right)$ is expressed as:

$$
V_{z}=V_{b} k_{1} k_{2} k_{3}
$$

where, $V_{b}=$ basis wind speed in $\mathrm{m} / \mathrm{s}$ at height $\mathrm{z}, k_{l}=$ probability factor (risk coefficient), $k_{2}=$ terrain, height and structure size factor, $k_{3}=$ topography factor and design wind pressure is expressed as: $\mathrm{p}_{\mathrm{z}}=0.6 \mathrm{~V}_{\mathrm{z}}^{2}$ where, $\mathrm{p}_{\mathrm{z}}=$ design wind pressure in $\mathrm{N} / \mathrm{m} 2$ at height $\mathrm{z}$

Wind loads are calculated for wind zone I, II, III, IV, V and VI, for which basic wind speed is respectively $33 \mathrm{~m} / \mathrm{s}, 39 \mathrm{~m} / \mathrm{s}, 44 \mathrm{~m} / \mathrm{s}, 47 \mathrm{~m} / \mathrm{s}, 50 \mathrm{~m} / \mathrm{s}$, and $55 \mathrm{~m} / \mathrm{s}$.

Following stipulations have been made. Terrain category - 2 (Open terrain with well scattered obstruction height having 1.5 to $10 \mathrm{~m}$ ), Class - B (Greatest vertical dimension between 20 to 50 $\mathrm{m}$ ), Risk coefficient $\mathrm{k} 1=1.08$ (Mean probable design life of structure $=100$ years) and Topographic factor $\mathrm{k} 3=1$ (Up-wind slope less than 30) 


\subsection{DYNAMIC LOAD}

IS 1893: part 1, 2002 has been used to access the dynamic load. Analysis has been carried out for Seismic zone II, III, IV, and V. Following stipulations have been made Importance factor (I) = 1.5 , Response reduction factor $(\mathrm{R})=4$ (steel frame with concentric braces), Soil condition as Medium and Damping Ratio - 2\%. (For steel structure). Table-VI shows the wind pressure calculation for $45 \mathrm{~m}$ tower with K-Bracing for the wind speed of $50 \mathrm{~m} / \mathrm{s}$. Force coefficient is calculated by calculating solidity ratio and using table given in IS 875 (part 3): 1987. Table VII shows the wind load calculation for $45 \mathrm{~m}$ high tower.

Similarly wind load was calculated for other wind speeds for different height of towers with different bracing patterns.

Table VI: Design Wind Pressure Acting on $45 \mathrm{~m}$ Tower $\left(\mathrm{kN} / \mathrm{m}^{2}\right)$ with K-type bracing

\begin{tabular}{|c|c|c|c|c|c|c|c|}
\hline $\begin{array}{l}\text { Panel } \\
\text { no. }\end{array}$ & $\begin{array}{l}\text { Bottom } \\
\text { width }\end{array}$ & $\begin{array}{l}\text { Top } \\
\text { width }\end{array}$ & $\begin{array}{l}\text { Height of } \\
\text { panel }\end{array}$ & $\begin{array}{c}\text { Height of panel from } \\
\text { bottom }\end{array}$ & K2 & \begin{tabular}{|l} 
Design \\
wind speed
\end{tabular} & $\begin{array}{c}\text { Design wind } \\
\text { pressure } \\
\left(\mathrm{kN} / \mathrm{m}^{2}\right) \\
\end{array}$ \\
\hline 1 & 6.5 & 5.92 & 4 & 4 & 0.98 & 52.92 & 1.6803 \\
\hline 2 & 5.92 & 5.34 & 4 & 8 & 0.98 & 52.92 & 1.6803 \\
\hline 3 & 5.34 & 4.76 & 4 & 12 & 0.996 & 53.784 & 1.7356 \\
\hline 4 & 4.76 & 4.18 & 4 & 16 & 1.026 & 55.404 & 1.8417 \\
\hline 5 & 4.18 & 3.6 & 4 & 20 & 1.05 & 56.7 & 1.9289 \\
\hline 6 & 3.6 & 3.3 & 2.5 & 22.5 & 1.0625 & 57.375 & 1.9751 \\
\hline 7 & 3.3 & 3 & 2.5 & 25 & 1.075 & 58.05 & 2.0218 \\
\hline 8 & 3 & 2.7 & 2.5 & 27.5 & 1.0875 & 58.725 & 2.0691 \\
\hline 9 & 2.7 & 2.4 & 2.5 & 30 & 1.1 & 59.4 & 2.1170 \\
\hline 10 & 2.4 & 2.18 & 2 & 32 & 1.105 & 59.67 & 2.1363 \\
\hline 11 & 2.18 & 1.95 & 2 & 34 & 1.11 & 59.94 & 2.1556 \\
\hline 12 & 1.95 & 1.73 & 2 & 36 & 1.115 & 60.21 & 2.1751 \\
\hline 13 & 1.73 & 1.5 & 2 & 38 & 1.12 & 60.48 & 2.1946 \\
\hline 14 & 1.5 & 1.5 & 1.75 & 39.75 & 1.125 & 60.75 & 2.2143 \\
\hline 15 & 1.5 & 1.5 & 1.75 & 41.5 & 1.128 & 60.912 & 2.2261 \\
\hline 16 & 1.5 & 1.5 & 1.75 & 43.25 & 1.133 & 61.182 & 2.2459 \\
\hline 17 & 1.5 & 1.5 & 1.75 & 45 & 1.1375 & 61.425 & 1.2638 \\
\hline
\end{tabular}


Civil Engineering and Urban Planning: An International Journal(CiVEJ) Vol.2,No.3, September 2015

Table VII: Wind Load Acting on $45 \mathrm{~m}$ Tower $(\mathrm{kN})$ with K-type bracing

\begin{tabular}{|c|c|c|c|c|c|c|c|}
\hline $\begin{array}{c}\text { Gross } \\
\text { area } \\
\left(\mathbf{m}^{2}\right) \\
\end{array}$ & $\begin{array}{c}\text { Net } \\
\text { area } \\
\left(\mathbf{m}^{2}\right)\end{array}$ & $\begin{array}{c}\text { C.G of } \\
\text { individual panel(m) }\end{array}$ & $\begin{array}{c}\text { C.G from } \\
\text { bottom } \\
(\mathbf{m})\end{array}$ & $\begin{array}{c}\text { Solidity } \\
\text { Ratio }\end{array}$ & $\begin{array}{c}\text { Force } \\
\text { coefficient }\end{array}$ & $\begin{array}{l}\text { Design wind } \\
\text { pressure }\end{array}$ & $\begin{array}{c}\text { Wind } \\
\text { Force }(\mathbf{k N})\end{array}$ \\
\hline 24.84 & 4.247 & 1.967 & 1.977 & 0.178 & 3.1 & 1.680 & 22.214 \\
\hline 22.52 & 4.267 & 1.966 & 5.967 & 0.184 & 3.2 & 1.680 & 22.971 \\
\hline 20.2 & 3.851 & 1.916 & 9.966 & 0.198 & 3.3 & 1.735 & 22.074 \\
\hline 17.88 & 3.654 & 1.949 & 13.962 & 0.262 & 3.3 & 1.841 & 22.203 \\
\hline 15.56 & 3.451 & 1.903 & 17.955 & 0.226 & 3.28 & 1.928 & 21.879 \\
\hline 8.625 & 2.367 & 1.284 & 21.953 & 0.273 & 3.1 & 1.975 & 14.432 \\
\hline 7.875 & 2.272 & 1.259 & 23.738 & 0.287 & 2.9 & 2.025 & 13.219 \\
\hline 7.125 & 2.177 & 1.207 & 26.216 & 0.302 & 2.8 & 2.038 & 12.451 \\
\hline 6.375 & 2.086 & 1.229 & 28.727 & 0.304 & 2.6 & 2.117 & 11.283 \\
\hline 4.58 & 1.475 & 0.988 & 31.229 & 0.398 & 2.8 & 2.134 & 8.476 \\
\hline 4.13 & 1.342 & 0.987 & 32.989 & 0.3217 & 2.6 & 2.216 & 7.524 \\
\hline 3.68 & 1.278 & 0.972 & 34.984 & 0.313 & 2.4 & 2.146 & 6.634 \\
\hline 3.23 & 1.208 & 0.964 & 36.987 & 0.379 & 2.3 & 2.124 & 6.075 \\
\hline 2.625 & 0.835 & 0.875 & 38.976 & 0.338 & 2.5 & 2.275 & 4.923 \\
\hline 2.625 & 0.885 & 0.875 & 40.625 & 0.338 & 2.5 & 2.205 & 4.995 \\
\hline 2.625 & 0.885 & 0.875 & 42.375 & 0.338 & 2.5 & 2.227 & 4.992 \\
\hline 2.625 & 0.885 & 0.875 & 44.125 & 0.338 & 2.5 & 2.238 & 5.317 \\
\hline
\end{tabular}

\section{RESULTS AND DISCUSSION}

\subsection{FOR WIND LOAD}

Joint displacement at the top of the tower and the stresses in the bottom leg of tower were obtained for towers of height $25 \mathrm{~m}, 35 \mathrm{~m}$, and $45 \mathrm{~m}$ with different bracing arrangements for wind zones I, II, III, IV, V, VI are tabulated in Table VIII and Table IX, respectively. 
Civil Engineering and Urban Planning: An International Journal(CiVEJ) Vol.2,No.3, September 2015

Table VIII: Joint displacement $(\mathrm{mm})$ at the top of the tower

\begin{tabular}{|c|c|c|c|c|c|c|}
\hline \multirow{2}{*}{$\begin{array}{c}\text { Tower } \\
\text { Height (m) }\end{array}$} & \multirow{2}{*}{ Wind zone } & \multicolumn{5}{|c|}{ Displacement (mm) } \\
\hline & & K-bracing & XBX-bracing & V- bracing & W- bracing & XX-bracing \\
\hline 25 & \multirow{3}{*}{$\begin{array}{c}\text { zone-I } \\
(33 \mathrm{~m} / \mathrm{s})\end{array}$} & 7.899 & 8.109 & 7.836 & 8.122 & 8.271 \\
\hline 35 & & 26.459 & 23.204 & 21.872 & 24.854 & 24.583 \\
\hline 45 & & 64.173 & 53.394 & 53.154 & 64.28 & 55.648 \\
\hline 25 & \multirow{3}{*}{$\begin{array}{l}\text { zone-II } \\
(39 \mathrm{~m} / \mathrm{s})\end{array}$} & 10.946 & 10.664 & 10.664 & 10.945 & 10.739 \\
\hline 35 & & 30.691 & 29.376 & 28.621 & 29.282 & 32.705 \\
\hline 45 & & 86.239 & 74.571 & 74.629 & 89.787 & 77.722 \\
\hline 25 & \multirow{3}{*}{$\begin{array}{l}\text { zone-III } \\
(44 \mathrm{~m} / \mathrm{s})\end{array}$} & 13.934 & 13.573 & 12.573 & 13.931 & 13.669 \\
\hline 35 & & 37.520 & 41.208 & 36.704 & 37.999 & 42.806 \\
\hline 45 & & 114.493 & 94.913 & 94.082 & 114.293 & 98.927 \\
\hline 25 & \multirow{3}{*}{$\begin{array}{l}\text { zone-IV } \\
(47 \mathrm{~m} / \mathrm{s})\end{array}$} & 15.9 & 15.487 & 15.487 & 16.895 & 20.282 \\
\hline 35 & & 43.67 & 53.018 & 41.021 & 45.075 & 52.135 \\
\hline 45 & & 137.817 & 108.295 & 107.83 & 130.414 & 112.875 \\
\hline 25 & \multirow{3}{*}{$\begin{array}{l}\text { zone-V } \\
(50 \mathrm{~m} / \mathrm{s})\end{array}$} & 20.99 & 20.443 & 20.443 & 20.981 & 21.282 \\
\hline 35 & & 56.009 & 62.064 & 55.79 & 56.221 & 56.934 \\
\hline 45 & & 162.323 & 142.951 & 151.83 & 172.162 & 158.988 \\
\hline 25 & \multirow{3}{*}{$\begin{array}{c}\text { zone-VI } \\
(55 \mathrm{~m} / \mathrm{s})\end{array}$} & 26.774 & 26.207 & 31.207 & 29.765 & 32.352 \\
\hline 35 & & 67.065 & 74.384 & 67.915 & 68.248 & 64.06 \\
\hline 45 & & 175.647 & 168.294 & 168.25 & 188.599 & 174.557 \\
\hline
\end{tabular}

Table IX: Member stresses (N/mm2) in bottom leg with different bracing

\begin{tabular}{|c|c|c|c|c|c|c|}
\hline \multirow{2}{*}{$\begin{array}{c}\text { Tower } \\
\text { Height } \\
\text { (m) }\end{array}$} & \multirow{2}{*}{$\begin{array}{l}\text { Wind } \\
\text { zone }\end{array}$} & \multicolumn{5}{|c|}{ Stress (N/mm2) } \\
\hline & & K-bracing & $\begin{array}{c}\text { XBX- } \\
\text { bracing }\end{array}$ & V-bracing & $\begin{array}{c}\text { W- } \\
\text { bracing }\end{array}$ & $\begin{array}{c}\text { XX- } \\
\text { bracing }\end{array}$ \\
\hline 25 & \multirow{3}{*}{$\begin{array}{c}\text { zone-I } \\
(33 \mathrm{~m} / \mathrm{s})\end{array}$} & 35.466 & 28.076 & 33.076 & 31.862 & 25.165 \\
\hline 35 & & 53.546 & 47.823 & 50.561 & 51.815 & 43.71 \\
\hline 45 & & 71.576 & 58.425 & 68.657 & 63.28 & 52.051 \\
\hline 25 & \multirow{3}{*}{$\begin{array}{c}\text { zone-II } \\
(39 \mathrm{~m} / \mathrm{s})\end{array}$} & 44.513 & 39.516 & 41.516 & 40.615 & 32.747 \\
\hline 35 & & 63.546 & 55.572 & 61.569 & 57.983 & 46.75 \\
\hline 45 & & 100.34 & 67.016 & 97.563 & 76.28 & 66.078 \\
\hline 25 & \multirow{2}{*}{$\begin{array}{l}\text { zone-III } \\
(44 \mathrm{~m} / \mathrm{s})\end{array}$} & 53.258 & 46.59 & 50.590 & 48.087 & 39.312 \\
\hline 35 & & 69.05 & 59.737 & 62.813 & 61.988 & 54.99 \\
\hline
\end{tabular}


Civil Engineering and Urban Planning: An International Journal(CiVEJ) Vol.2,No.3, September 2015

\begin{tabular}{|c|c|c|c|c|c|c|}
\hline 45 & & 84.33 & 68.035 & 78.05 & 74.28 & 67.740 \\
\hline 25 & \multirow{3}{*}{$\begin{array}{l}\text { zone-IV } \\
(47 \mathrm{~m} / \mathrm{s})\end{array}$} & 53.992 & 53.002 & 56.013 & 55.47 & 50.412 \\
\hline 35 & & 77.502 & 66.785 & 75.523 & 71.155 & 55.51 \\
\hline 45 & & 127.829 & 90.259 & 111.47 & 102.975 & 76.018 \\
\hline 25 & \multirow{3}{*}{$\begin{array}{l}\text { zone-V } \\
(50 \mathrm{~m} / \mathrm{s})\end{array}$} & 73.842 & 55.528 & 56.528 & 52.412 & 44.808 \\
\hline 35 & & 95.531 & 73.147 & 75.102 & 79.592 & 64.451 \\
\hline 45 & & 154.008 & 97.037 & 121.47 & 109.065 & 85.451 \\
\hline 25 & \multirow{3}{*}{$\begin{array}{l}\text { zone-VI } \\
(55 \mathrm{~m} / \mathrm{s})\end{array}$} & 76.132 & 59.761 & 57.874 & 54.561 & 47.931 \\
\hline 35 & & 98.619 & 74.487 & 77.448 & 83.034 & 66.614 \\
\hline 45 & & 177.855 & 100.851 & 137.358 & 124.63 & 87.756 \\
\hline
\end{tabular}

Graphs are plotted between displacement at the top of tower and tower height for a particular bracing pattern in all the wind zones (I to VI) and are shown in Fig.2 (a-e). Graphs are also plotted between displacement at the top of tower and tower height for different bracing patterns in a particular zone and are shown in Fig. 3(a-f).

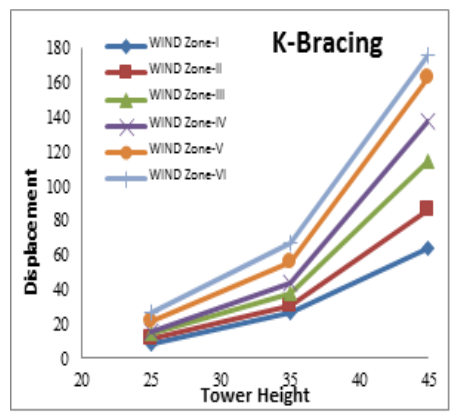

(a)

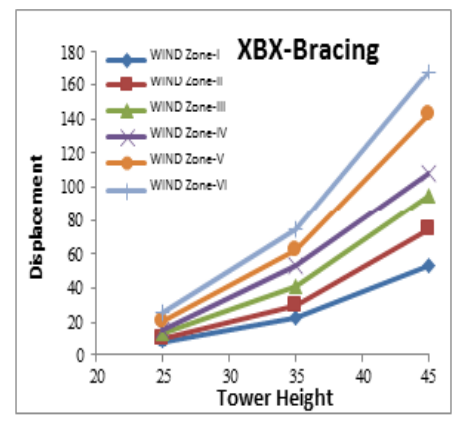

(b)

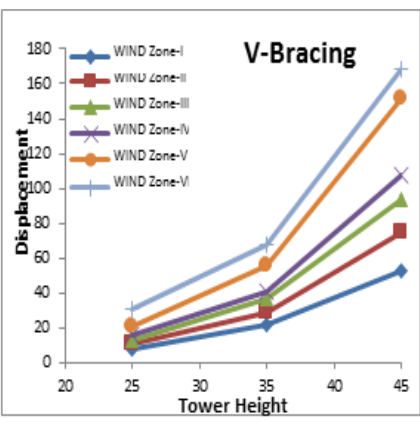

(c)

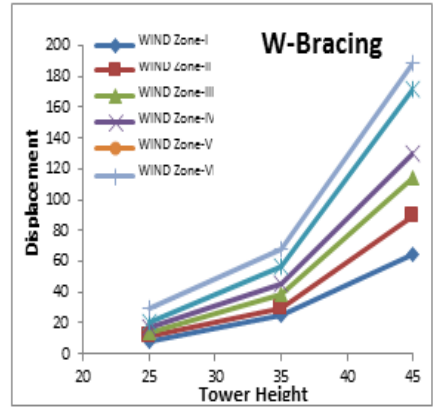

(d)

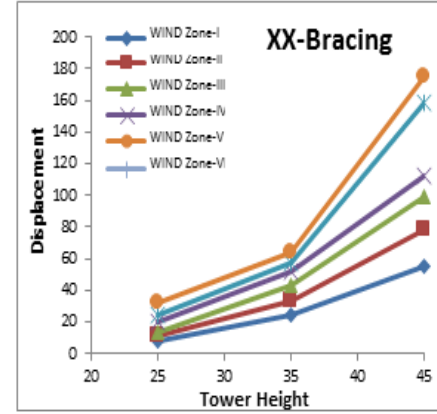

(e)

Fig. 2(a-e): Comparison of displacement at the top of the tower for all wind zone 
It was concluded from Fig. 2(a-e) that displacement increases with the wind zone from I to VI and found to be maximum for $\mathrm{W}$-bracing and minimum for $\mathrm{K}$-bracing.

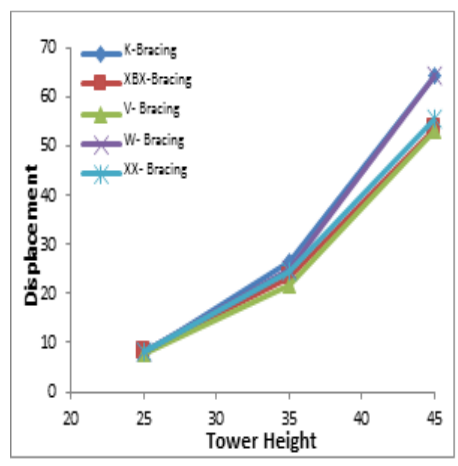

(a)

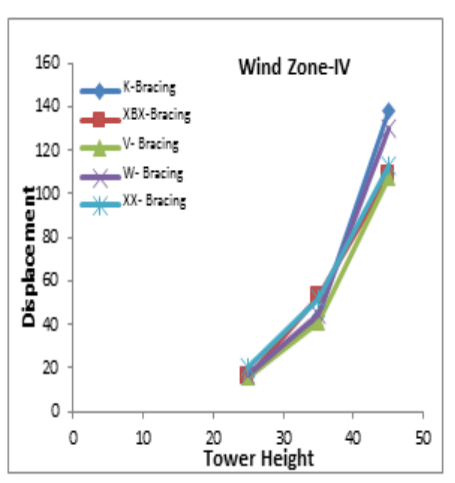

(d)

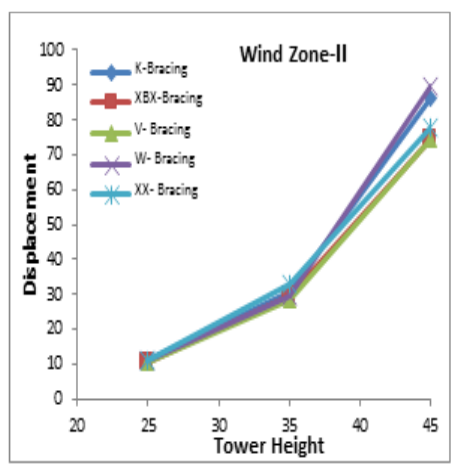

(b)

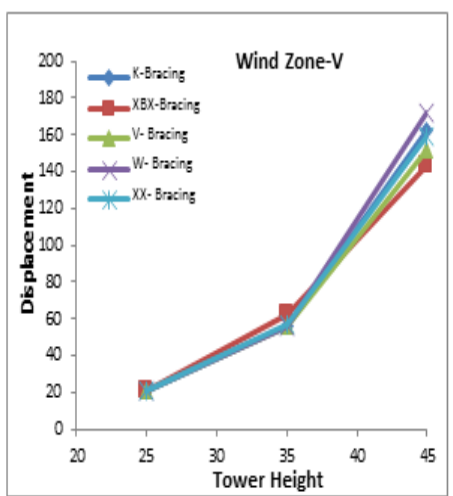

(e)

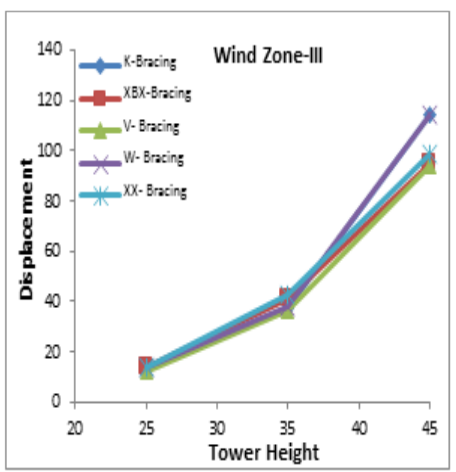

(c)

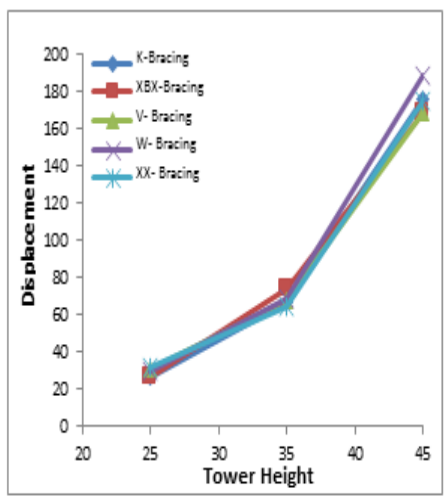

(f)

Fig 3 (a-f): Variation of displacement at the top of the tower for different bracing pattern

Fig. 3(a-f) shows variation of displacement at the top of the tower for different bracing patterns for all the wind zones. Tower heights between $25 \mathrm{~m}$ to $35 \mathrm{~m}$, with different bracing patterns, do not reveal much difference in displacement.

For wind zone I to IV tower height between $35 \mathrm{~m}$ to $45 \mathrm{~m}$ having $\mathrm{K}$-Bracing or W-Bracing gives maximum value of displacement and $\mathrm{V}$-Bracing gives minimum value of displacement.

For wind zone V and VI tower height between $35 \mathrm{~m}$ to $45 \mathrm{~m}$ having $\mathrm{W}$-Bracing gives maximum value of displacement and $\mathrm{V}$-Bracing or XBX -Bracing gives minimum value of displacement.

Stresses in the bottom leg members of tower vs. tower height for a particular bracing pattern in all wind zones (I to VI), are shown in Fig. 4(a-e). Graphs are also plotted between stresses in the bottom leg members of tower and tower height for different bracing patterns in a particular zone and are shown in Fig. 5(a-f).

It was concluded from Fig. 4(a-e) that stress increases with variation of wind zone from I to VI and found to be maximum for $\mathrm{K}$-bracing and minimum for $\mathrm{XX}$-bracing. 
Civil Engineering and Urban Planning: An International Journal(CiVEJ) Vol.2,No.3, September 2015

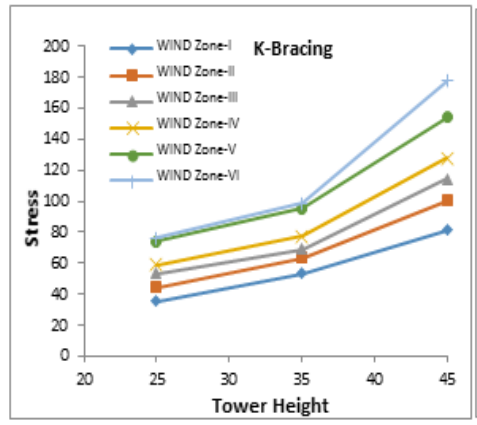

(a)

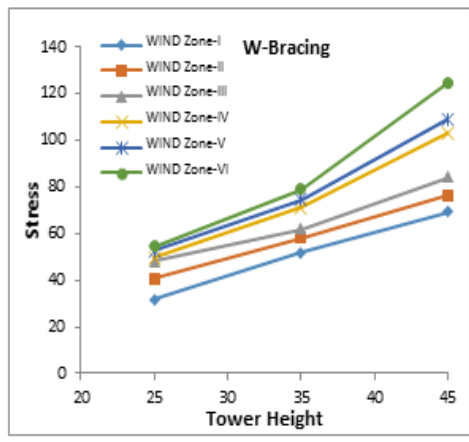

(d)

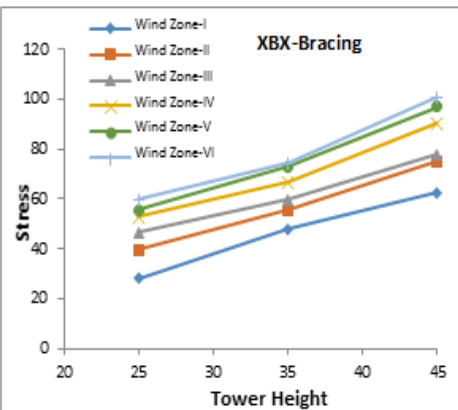

(b)

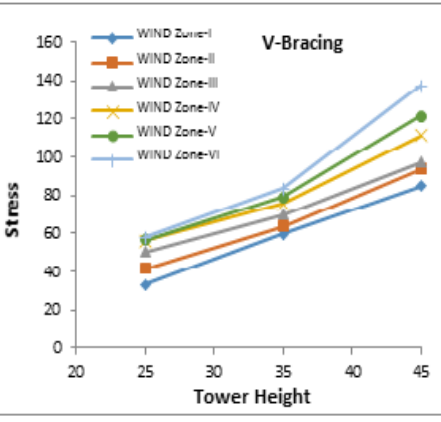

(c)

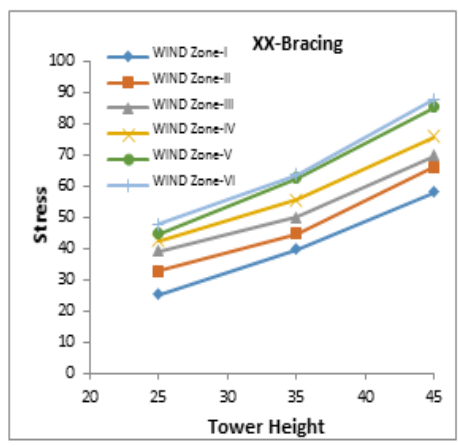

(e)

Fig 4 (a-e): Variation of stress at the bottom leg of the tower in all wind zones

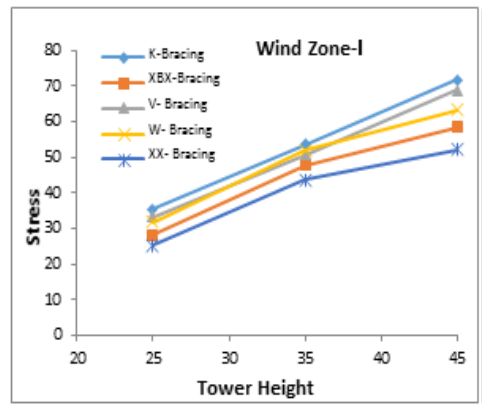

(a)

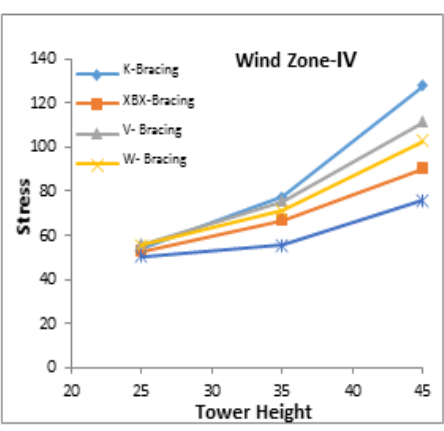

(d)

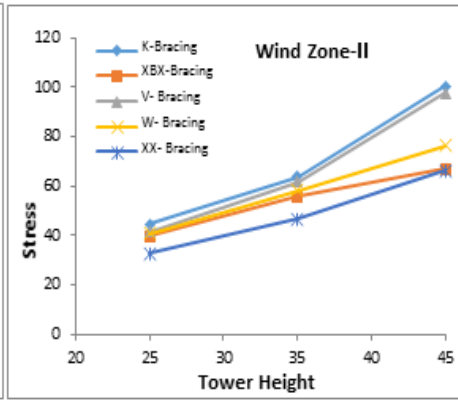

(b)

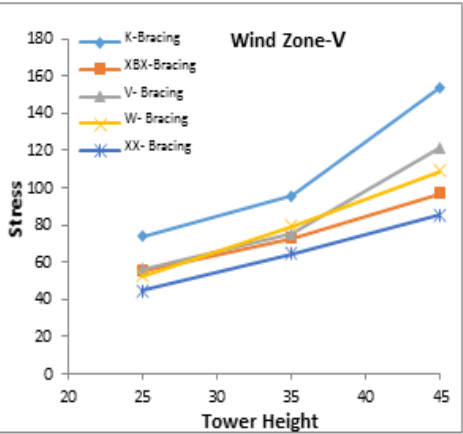

(e)

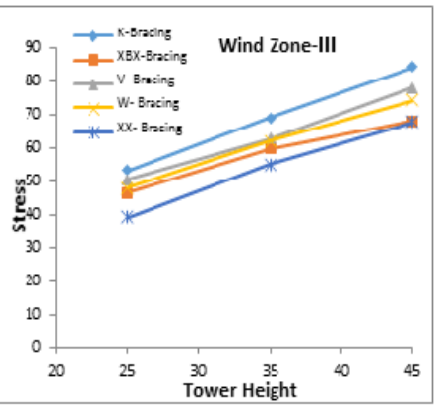

(c)

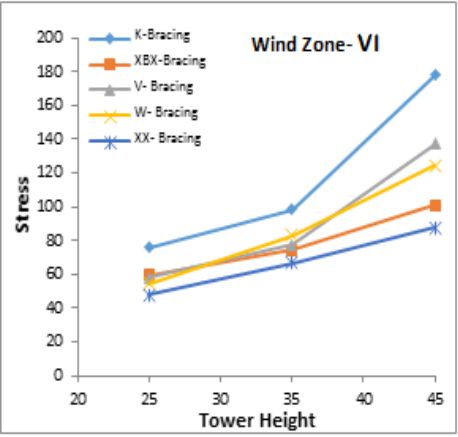

(f)

Fig 5(a-f): Variation of Stress at the top of the tower for different bracing pattern 
Figure 5(a-f) shows variation of stress in the bottom leg of the tower with respect to tower height in a wind zone for different possible arrangements of bracing patterns. Stress increases with the increase in the height of the Tower. Results show that the increase in stress with height in the bottom leg members of the tower from wind zone I to wind zone VI is maximum for K-Bracing and it is minimum for $\mathrm{XX}$-Bracing.

\subsection{FOR SEISMIC LOADS}

\section{Modal Analysis}

Modal analysis of the tower structures are carried out and the modal parameters such as natural frequency and mode shapes are obtained. The figure 6 shows the first mode shape of $45 \mathrm{~m}$ tower with different bracings. The natural frequencies are tabulated in table X.
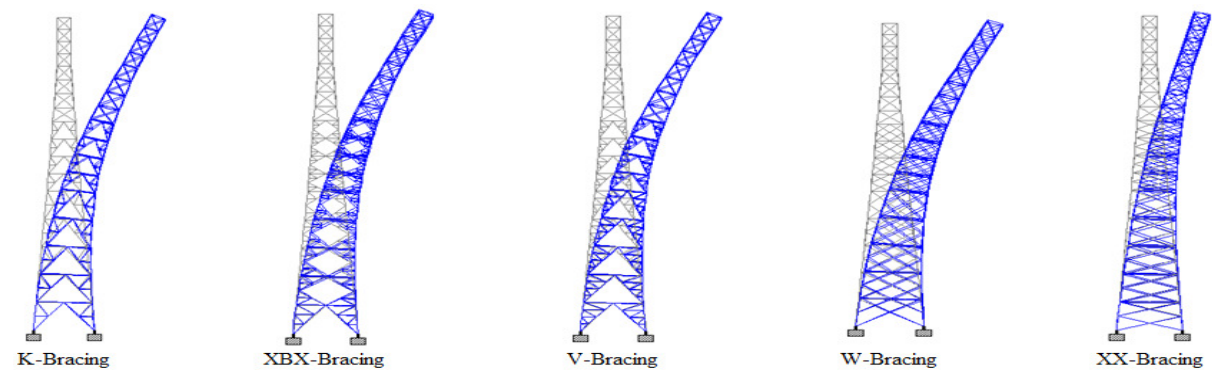

Fig 6: First Mode shape of 45 m Towers with Different Bracings Considered

Table X: Natural Frequencies of Telecommunication Towers (Hz)

\begin{tabular}{|c|c|c|c|c|c|c|}
\hline \multirow{3}{*}{ Height } & \multirow{2}{*}{ Mode } & \multicolumn{5}{|c|}{ Bracing } \\
\cline { 3 - 7 } & & $\begin{array}{c}\text { K- } \\
\text { Bracing }\end{array}$ & $\begin{array}{c}\text { XBX- } \\
\text { Bracing }\end{array}$ & V-Bracing & $\begin{array}{c}\text { W- } \\
\text { Bracing }\end{array}$ & $\begin{array}{c}\text { XX- } \\
\text { Bracing }\end{array}$ \\
\cline { 3 - 7 } & Mode1 & 3.802 & 3.172 & 2.919 & 2.95 & 3.125 \\
\hline \multirow{3}{*}{45} & Mode2 & 3.802 & 3.172 & 2.919 & 2.95 & 3.125 \\
\cline { 2 - 7 } & Torsion & 9.420 & 8.279 & 7.085 & 8.05 & 8.801 \\
\hline \multirow{3}{*}{35} & Mode1 & 4.51 & 3.907 & 3.986 & 4.298 & 4.155 \\
\cline { 2 - 7 } & Mode2 & 4.51 & 3.907 & 3.986 & 4.298 & 4.155 \\
\cline { 2 - 7 } & Torsion & 10.404 & 10.520 & 7.891 & 8.319 & 11.212 \\
\hline \multirow{3}{*}{25} & Mode1 & 7.392 & 7.439 & 7.042 & 7.536 & 7.274 \\
\cline { 2 - 7 } & Mode2 & 7.392 & 7.439 & 7.042 & 7.536 & 7.274 \\
\cline { 2 - 7 } & Torsion & 10.063 & 9.097 & 9.522 & 8.028 & 8.238 \\
\hline
\end{tabular}

Table $\mathrm{X}$ indicates that natural frequency decreases as height of the tower increases. Decrease in natural frequency is $63.9 \%$ when height increases from $25 \mathrm{~m}$ to $35 \mathrm{~m}$ and decrease in natural frequency is $18.68 \%$ when height increases from $35 \mathrm{~m}$ to $45 \mathrm{~m}$.

As the tower height increases the mass starts to play a major role than the stiffness of the structure there by reducing the natural frequency of the structure. The frequency of the tower with Vbracing displayed the least natural frequency since its stiffness was found to be higher due to more weight of the structure as compared to other models. 


\section{Response Spectrum Analysis-}

Joint displacement at the top of the tower and the member stress at the base of the tower obtained after the Response spectrum analysis of the towers of height $25 \mathrm{~m}, 35 \mathrm{~m}$, and $45 \mathrm{~m}$ using different bracing pattern for earthquake zone II, III, IV, V are tabulated in Table XI and Table XII respectively.

Table XI: Joint displacement at the top of the tower

\begin{tabular}{|c|c|c|c|c|c|c|}
\hline \multirow{2}{*}{$\begin{array}{l}\text { Tower } \\
\text { Height } \\
\text { (m) }\end{array}$} & \multirow[b]{2}{*}{ Zone } & \multicolumn{5}{|c|}{ Displacement (mm) } \\
\hline & & K-bracing & XBX-bracing & $\begin{array}{l}\text { V- } \\
\text { bracing }\end{array}$ & $\begin{array}{l}\text { W- } \\
\text { bracing }\end{array}$ & XX-bracing \\
\hline 25 & \multirow{3}{*}{ zone-II } & 0.88 & 1.87 & 0.76 & 0.94 & 1.06 \\
\hline 35 & & 3.79 & 4.12 & 3.67 & 3.82 & 3.96 \\
\hline 45 & & 8.44 & 9.33 & 8.39 & 8.56 & 8.67 \\
\hline 25 & \multirow{3}{*}{ zone-III } & 2.67 & 3.58 & 2.58 & 2.91 & 3.15 \\
\hline 35 & & 6.85 & 7.32 & 6.64 & 6.95 & 7.19 \\
\hline 45 & & 15.26 & 15.86 & 14.97 & 15.37 & 15.46 \\
\hline 25 & \multirow{3}{*}{ zone-IV } & 3.85 & 4.38 & 3.58 & 4.06 & 4.19 \\
\hline 35 & & 9.24 & 10.34 & 9.07 & 9.36 & 9.68 \\
\hline 45 & & 18.57 & 19.34 & 18.34 & 18.74 & 18.95 \\
\hline 25 & \multirow{3}{*}{ zone-V } & 5.27 & 6.53 & 5.04 & 5.58 & 5.93 \\
\hline 35 & & 14.86 & 15.58 & 14.43 & 14.97 & 15.24 \\
\hline 45 & & 32.09 & 32.92 & 31.79 & 32.42 & 32.73 \\
\hline
\end{tabular}

Table XII: Member stress at the base of the tower

\begin{tabular}{|c|c|c|c|c|c|c|}
\hline \multirow{2}{*}{$\begin{array}{c}\text { Tower } \\
\text { Height (m) }\end{array}$} & \multirow[b]{2}{*}{ zone } & \multicolumn{5}{|c|}{ Stress (N/mm2) } \\
\hline & & K-bracing & $\begin{array}{c}\text { XBX- } \\
\text { bracing }\end{array}$ & V-bracing & $\begin{array}{c}\text { W- } \\
\text { bracing }\end{array}$ & $\begin{array}{c}\text { XX- } \\
\text { bracing }\end{array}$ \\
\hline 25 & \multirow{3}{*}{ zone-II } & 3.76 & 3.87 & 3.63 & 2.99 & 3.15 \\
\hline 35 & & 6.28 & 6.72 & 6.18 & 5.86 & 6.12 \\
\hline 45 & & 8.89 & 9.83 & 8.73 & 8.05 & 8.43 \\
\hline 25 & \multirow{3}{*}{ zone-III } & 5.27 & 5.98 & 5.15 & 4.81 & 4.95 \\
\hline 35 & & 7.89 & 8.26 & 7.54 & 7.05 & 7.39 \\
\hline 45 & & 10.89 & 11.46 & 10.57 & 10.37 & 10.43 \\
\hline 25 & \multirow{3}{*}{ zone-IV } & 6.56 & 6.88 & 6.38 & 6.08 & 6.26 \\
\hline 35 & & 9.73 & 9.93 & 9.49 & 9.24 & 9.38 \\
\hline 45 & & 12.57 & 12.84 & 12.43 & 12.22 & 12.35 \\
\hline 25 & \multirow{3}{*}{ zone-V } & 8.27 & 8.74 & 7.98 & 7.63 & 7.85 \\
\hline 35 & & 11.86 & 12.21 & 11.63 & 11.36 & 11.44 \\
\hline 45 & & 16.79 & 17.16 & 16.63 & 16.42 & 16.58 \\
\hline
\end{tabular}

Graphs are plotted between displacement at the top of tower and tower height for a particular bracing pattern in all earthquake zones (II to V) and shown in figure 7(a-e). Graphs are also plotted between displacement at the top of tower and tower height for different bracing pattern in a particular zone and shown in figure $8(\mathrm{a}-\mathrm{d})$. 
Civil Engineering and Urban Planning: An International Journal(CiVEJ) Vol.2,No.3, September 2015

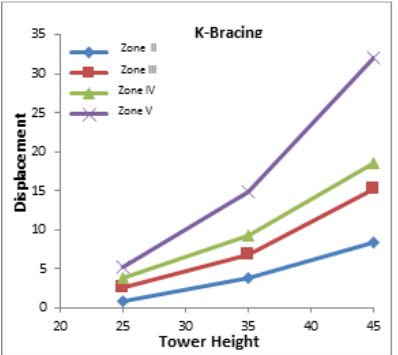

(a)

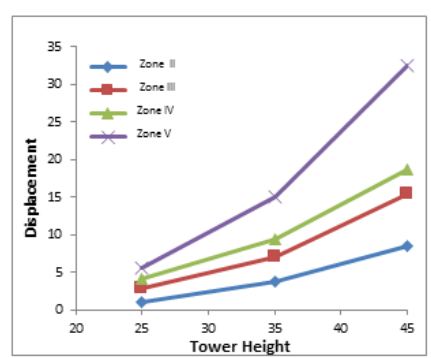

(d)

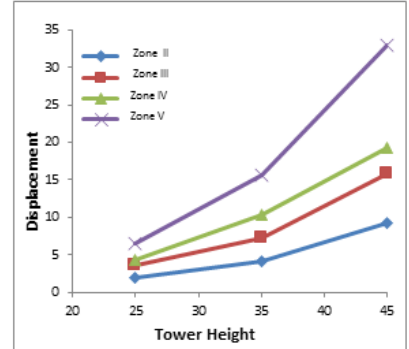

(b)

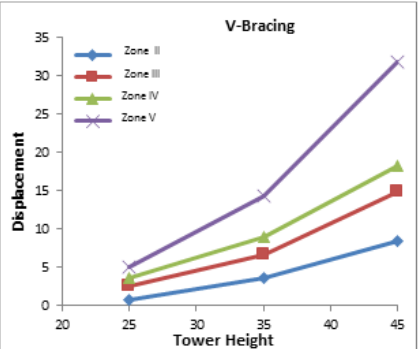

(c)

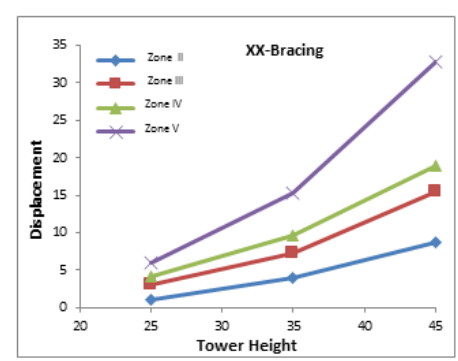

(e)

Fig 7(a-e): variation of Displacement at the top of the tower for different seismic zones

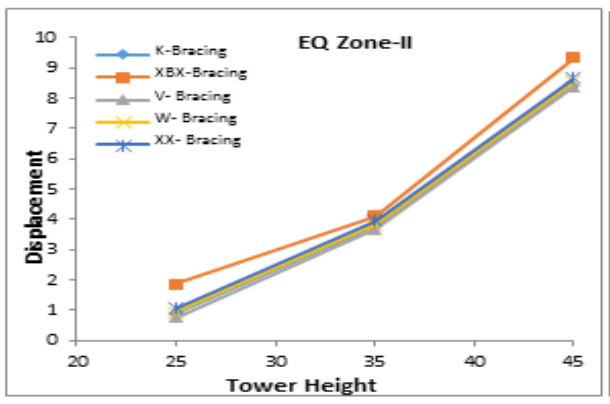

(a)

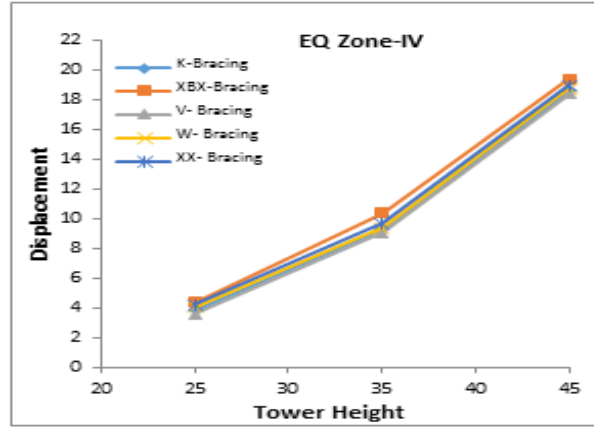

(c)

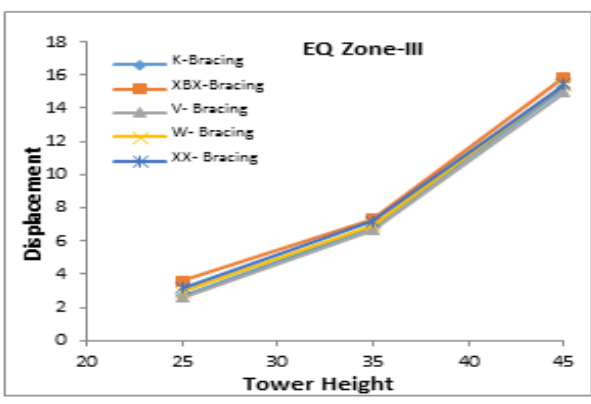

(b)

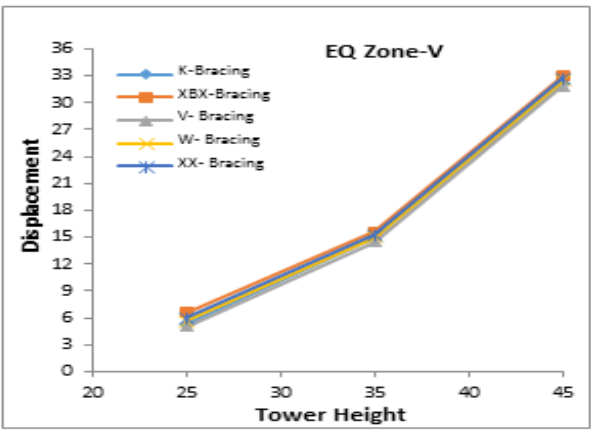

(d)

Fig 8(a-d): Variation of displacement with tower height for different Bracing Pattern

Graphs are plotted between stress in the bottom leg members of tower and tower height for a particular bracing pattern in all EQ zones (II-V) and shown in figure 9(a-e). Graphs are also plotted between stress in the bottom leg members of tower and tower height for different bracing pattern in a particular zone and shown in figure $10(\mathrm{a}-\mathrm{d})$. 


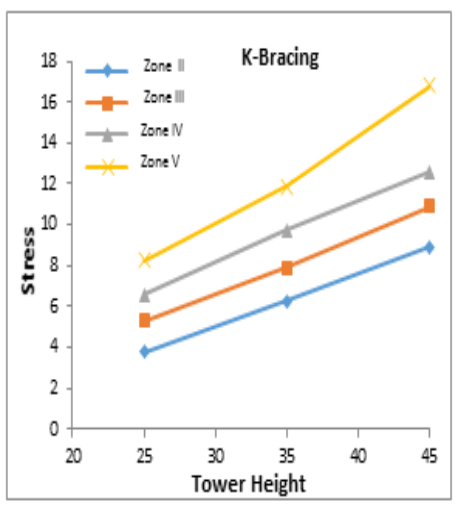

(a)

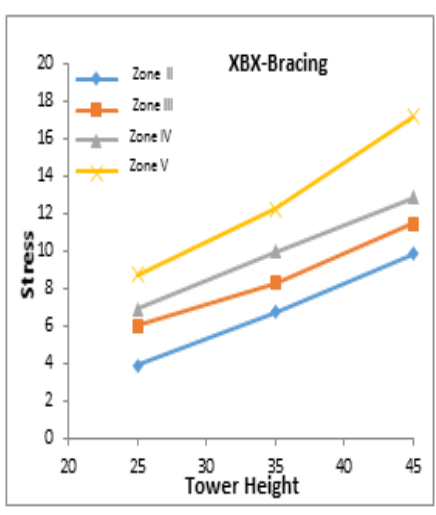

(b)

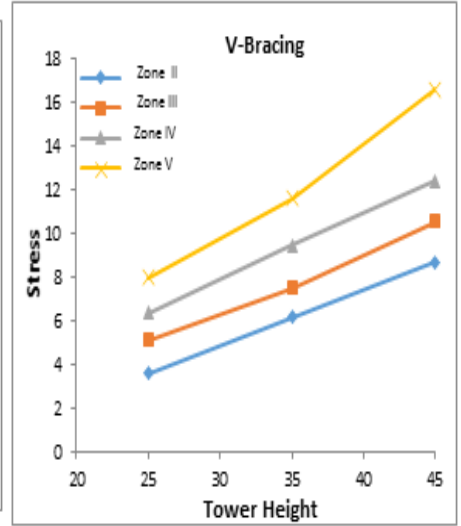

(c)

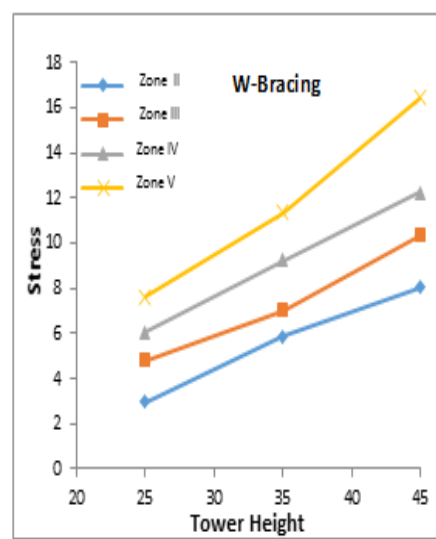

小

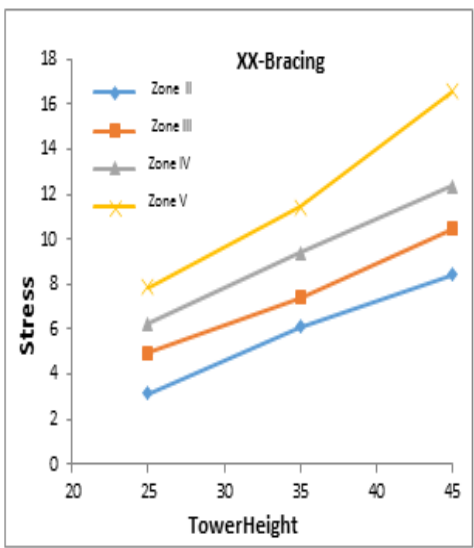

,

Fig 9 (a-e): variation of stress with tower height for different bracing pattern

Figure 7(a-e) shows variation of Displacement at the top of the tower for different wind zones with the tower height. There is a steep increase in the displacement in earthquake zone $\mathrm{V}$ for every type of bracing pattern. Change in displacement with the earthquake zone is maximum for $\mathrm{W}$-bracing and it is minimum for $\mathrm{K}$-Bracing.

Figure 8(a-d) Variation of displacement with tower height for different Bracing Pattern showes that from all the types of bracing pattern in a earthquake zone, XBX-Braced tower shows maximum value of displacement and V-braced tower shows mimimum value of displacement for the given height of the tower.

Figure 9(a-e) Variation of stress with tower height for all earthquake zones for different Bracing pattern shows that change in stress is maximum for earthquake zone $-\mathrm{V}$ for any type of Bracing pattern. From Zone II to zone III increase in stress is about 17\%, Zone III to zone IV increase in stress is about $12 \%$ and from Zone IV to zone V increase in stress is about $24 \%$.

Change in stress with the change in earthquake zone for a particular tower height is maximum for $\mathrm{W}$-Bracing and it is minimum for $\mathrm{K}$-Bracing. 
Civil Engineering and Urban Planning: An International Journal(CiVEJ) Vol.2,No.3, September 2015

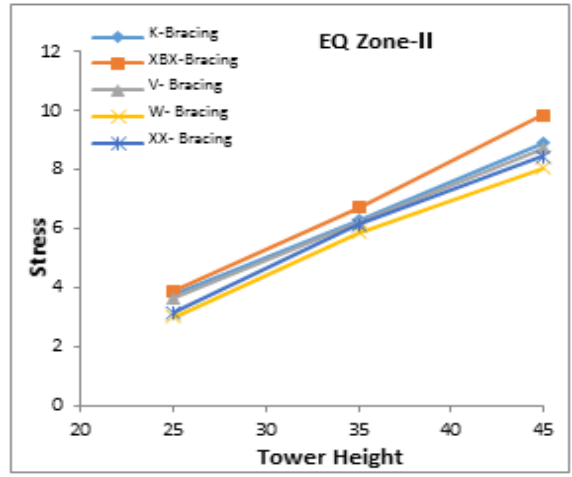

(a)

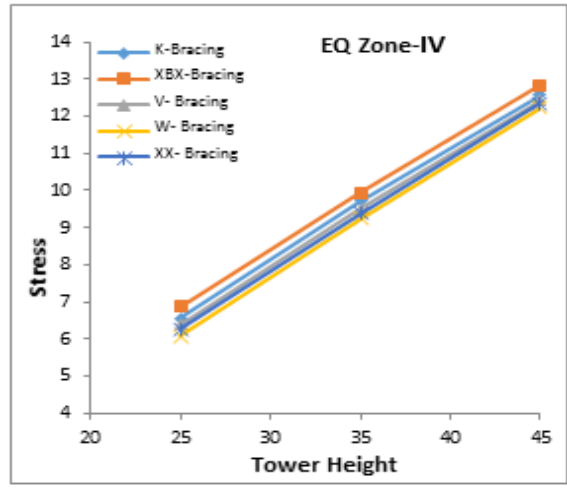

(c)

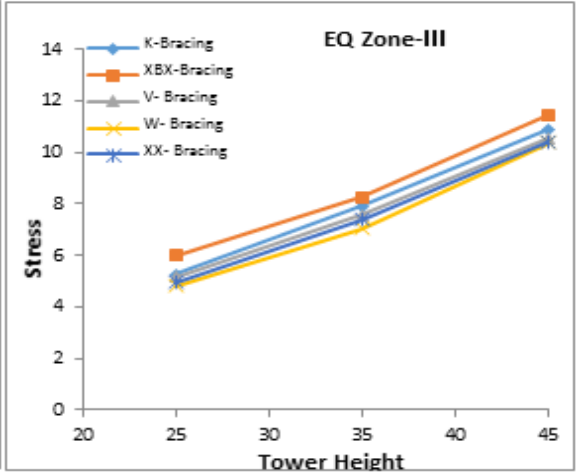

(b)

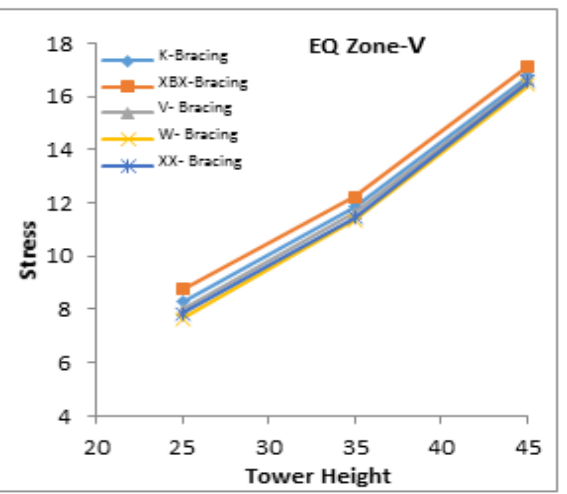

(d)

Fig 10(a-d): Variation of stress with tower height for all EQ zone

Figure 10(a-d) shows variation of stress with tower height for different bracing pattern shows that for all earthquake zones stress in the bottom leg members of the tower is maximum for XBXBracing and it is minimum for $\mathrm{W}$-Bracing.

Weight Vs. Tower Height

Table XIII: Weight with different bracing

\begin{tabular}{|c|c|c|c|c|c|}
\hline \multirow{2}{*}{ Tower Height (m) } & \multicolumn{5}{|c|}{ Weight } \\
\cline { 2 - 6 } & k-bracing & XBX-bracing & V-bracing & W-bracing & XX-bracing \\
\hline 45 & 190.72 & 173.64 & 139.33 & 155.68 & 146.72 \\
\hline 35 & 111.204 & 103.42 & 76.406 & 96.526 & 91.204 \\
\hline 25 & 68.201 & 58.201 & 33.942 & 52.201 & 48.201 \\
\hline
\end{tabular}




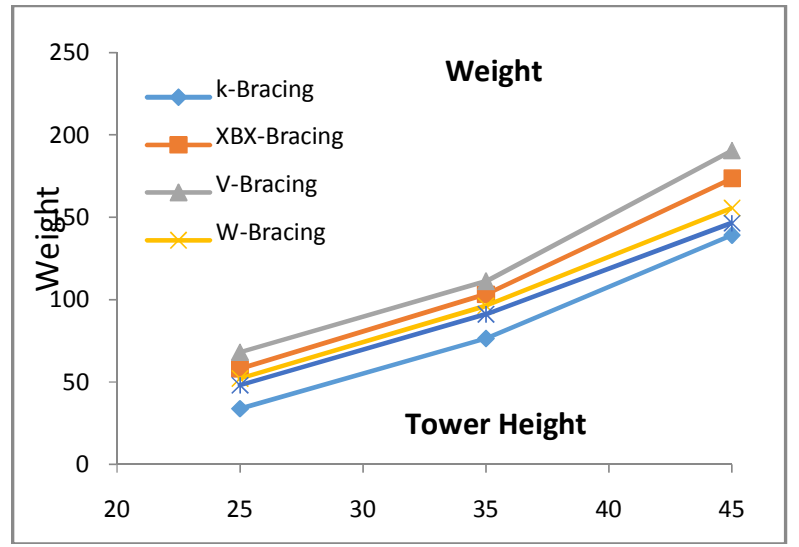

Fig 11: Comparison of Weight with Tower height for different Bracing system

Figure-11 indicates that weight increases as height of the tower increases. Increase in weight is $41.07 \%$ when height increases from $25 \mathrm{~m}$ to $35 \mathrm{~m}$ and increase in weight is $10.42 \%$ when height increases from $35 \mathrm{~m}$ to $45 \mathrm{~m}$. Weight is maximum for $\mathrm{V}$-bracing and minimum for K-bracing for the same tower height.

\section{CONCLUSIONS}

1). Displacement increases with the increase in speed of the wind. Results displayed that the increase in the displacement from wind zone I to wind zone VI is maximum for W-Bracing and it is minimum for $\mathrm{K}-\mathrm{Bracing}$.

2). For all wind zones tower height between $25 \mathrm{~m}$ to $35 \mathrm{~m}$ with different bracing patterns do not show much difference in displacement.

For wind zone I to IV, tower height between $35 \mathrm{~m}$ to $45 \mathrm{~m}$ having $\mathrm{K}$-Bracing or W-Bracing gives maximum value of displacement and $\mathrm{V}$-Bracing gives minimum value of displacement.

For wind zone $\mathrm{V}$ and VI tower height between $35 \mathrm{~m}$ to $45 \mathrm{~m}$ having $\mathrm{W}$-Bracing gives maximum value of displacement and $\mathrm{V}$-Bracing or XBX -Bracing gives minimum value of displacement.

3). Stress increases with the increase in speed of the wind. Results show that the increase in stress in the bottom leg members of the tower from wind zone I to wind zone VI is maximum for KBracing and it is minimum for XX-Bracing.

4). Stress increases with the increase in the height of the Tower. Results show that the increase in stress is maximum for $\mathrm{K}$-Bracing and it is minimum for XX-Bracing.

5). There is a steep increase in the displacement in Earthquake zone $\mathrm{V}$ for all considered type of bracing pattern. Results show that the increase in the displacement from earthquake zone II to VI is maximum for $\mathrm{W}$-Bracing and it is minimum for $\mathrm{K}$-Bracing.

6). For all earthquake zones stress at the bottom leg members of the tower is maximum for XBXBracing and it is minimum for $\mathrm{W}$-Bracing. 
7). The change in weight when height increases from 25 to $35 \mathrm{~m}$ is about $41.07 \%$ and from 35 to $45 \mathrm{~m}$ is $26.02 \%$.Weight is maximum for $\mathrm{V}$-bracing and minimum for $\mathrm{K}$-bracing for the same tower height.

8). There is a gradual decrease in the natural frequency of the structure as the height of tower increases. This is due to the influence of mass as the height increases the mass starts to play predominate role than stiffness there by reducing the natural frequency of the structure.

The comparison shows that the frequency of the tower with $\mathrm{V}$ - bracing have the least natural frequency since its stiffness is higher as the weight of the structure is more and as compared to others.

9). From the above analysis it can be concluded that the wind is the predominate factor in the tower modeling than the seismic forces but the seismic effect cannot be fully neglected as observed from the results.

10). From the above analysis it can be concluded that sub divided V-Bracing gives satisfactory result in wind analysis, modal analysis and response spectrum analysis for all considered wind and earthquake zones mentioned in IS code.

\section{Recommended Bracing Pattern}

\begin{tabular}{|c|c|c|c|c|}
\hline \multirow{2}{*}{ Wind zone } & \multicolumn{4}{|c|}{ Earthquake Zone } \\
\cline { 2 - 5 } & Zone -II & Zone -III & Zone -IV & Zone -V \\
\hline Zone-I & W-Bracing & XX- Bracing & XBX- Bracing & K- Bracing \\
\hline Zone -II & W- Bracing & XX- Bracing & K- Bracing & K- Bracing \\
\hline Zone -III & XX- Bracing & XBX- Bracing & K- Bracing & V- Bracing \\
\hline Zone -IV & XBX- Bracing & XBX- Bracing & K- Bracing & V- Bracing \\
\hline Zone -V & XBX- Bracing & K- Bracing & V- Bracing & V- Bracing \\
\hline Zone -VI & XBX- Bracing & K- Bracing & V- Bracing & V- Bracing \\
\hline
\end{tabular}

\section{REFERENCES}

[1] Rajasekharan, J. \& Vijaya, S. (2014) Analysis of Telecommunication Tower Subjected to Seismic \& Wind loading. International Journal of Advancement in Engineering Technology, Management and applied science.

[2] Jesumi, A. \& Rajendran, M. G. (2013) Optimal Bracing System for Steel Towers. International Journal of Engineering Research and Applications.

[3] Bhatt, R., Pandey, A. D. \& Prakash, V. (2013) Influence of modeling in the response of steel lattice mobile tower under wind loading. International Journal of Scientific Engineering and Technology.

[4] Amiri, G. \& Boostan, A. (2002) Dynamic Response of Antenna-Supporting Structures. 4th Structural Specialty Conference of the Canadian Society for Civil Engineering. p.1-9.

[5] Siddesha, H. (2010) Wind Analysis of Microwave Antenna Towers. International Journal of Applied Engineering Research.

[6] Vidya, M. \& Abhijeet, C. (2012) Structural Response of Lattice Steel Masts for Seismic Loading. IOSR Journal of Mechanical and Civil Engineering.

[7] Jesumi, A. \& Rajendran, M.G. (2013) Optimal Bracing System for Steel Towers. International Journal of Engineering Research and Applications.

[8] Da Silva, J.G.S., Da S. Vellasco, P.C.G., De Andrade, S.A.L. \& De Oliveir, M.I.R. (2005). Structural assessment of current steel design models for transmission and telecommunication towers. Journal of Constructional Steel Research.

[9] IS 800:1984, Indian Standard Code of Practice for General Construction in Steel, Bureau of Indian Standards, New Delhi. 
[10] IS 802 (part1/sec1): 1995, Indian Code of Practice for Use of Structural Steel in Overhead Transmission Line Towers, Part 1: Materials, Loads and Permissible Stresses. Bureau of Indian Standards, New Delhi.

[11] IS 875 (part 3):1987, Indian Code of Practice for Design Loads (other than Earthquake) for Buildings and Structures, Part 3: Wind Loads. Bureau of Indian Standards, New Delhi.

[12] IS 1893 (part 1): 2002, Indian Standard Criteria for Earthquake Resistant Design of Structures, Part 1: General Provisions and Buildings. Bureau of Indian Standards, New Delhi.

\section{AUTHORS}

Mr.Keshav Kumar Sharma is the Research Scholar in the Department of Civil Engineering at Motilal Nehru National Institute of Technology, Allahabad, India.

Dr.S. K. Duggal is currently Professor in the Department of Civil Engineering at Motilal Nehru National Institute of Technology, Allahabad, India.

Mr. Deepak Kumar Singh is the Research Scholar in the Department of Civil Engineering at Motilal Nehru National Institute of Technology, Allahabad, India.

Dr.A. K. Sachanis currently Professor in the Department of Civil Engineering at Motilal Nehru National Institute of Technology, Allahabad, India.
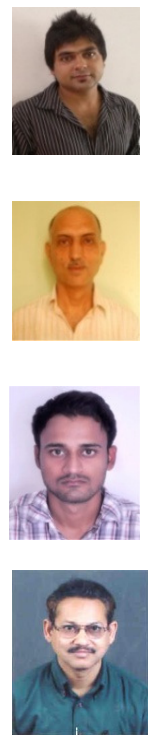